УДК 333

\title{
ОСНОВНЫЕ АСПЕКТЫ УЧЕТА ОСНОВНЫХ СРЕДСТВ
}

\section{Семенихина Н.А.} магистрант Научный руководитель: Плотникова О.В. д-р экон. наук, профессор Новосибирский государственный университет экономики и управления «НИНХ»

Аннотация: В статье рассматривается подход к учету и анализу основных средств. Он служит для создания аналитической информации, способствующей пониманию процесса управления основными средствами.

Ключевые слова: основные средства, фондоотдача, справедливая стоимость, оценка основных средств.

\section{FIXED ASSETS ACCOUNTING PROBLEMS}

\section{N.A. Semenikhina Scientific adviser: O.V. Plotnikova}

\begin{abstract}
The article discusses the approach to accounting and analysis of fixed assets. It serves to create analytical information to understand how to manage fixed assets.
\end{abstract}

Keywords: fixed assets, fund efficiency, fair value, fixed asset valuation.

Основные фонды выступают ключевым источником «добычи» прибыли и показывают, какой есть производственный потенциал организации. Данные по учету и анализу основных фондов подводят к необходимости замены нерентабельных фондов и выводу из строя оборудования с высокими показателями морального и физического износа. Для учета основных средств используют методические указания по ведению бухгалтерского учета $[1,2,3]$.

При их постановке на баланс предприятия определяют их стоимость. «Признание» стоимости основных средств происходит на основании договора. Это может быть договор купли и продажи, дарения, пожертвования, 
безвозмездного пользования. Стоимость основных средств должна быть рыночной. Она равна «справедливой стоимости договорных обязательств, основанной на принципе допущения о способности генерировать экономические выгоды при их преобразовании в факты хозяйственной жизни в будущем» [5].

То есть «справедливой стоимостью основных средств, способных сгенерировать стоимость продуктов» не всегда просто определить рыночную стоимость крупного основного средства. Это одна из сложностей бухгалтерского учета основных средств.

Следующий этап учета. После определения стоимости основных средств, находят по «Общероссийскому классификатору ОК013-2014 (СНС 2008) "Общероссийский классификатор основных фондов" [1,2,3,4], ФСБУ 6/2020. «Основные средства» к какой группе основных средств относится конкретный объект. Из классификатора определяют, к какой амортизационной группе относится конкретное основное средство, чтобы начислять амортизацию. Затем выбирают способ амортизации из способов, которые используют для основных средств. И на основании учетной политики, где должен быть описан порядок бухгалтерского учета основных средств на этом предприятии. Также, на основании протокола о принятии объекта основных средств комиссией, ставят на баланс предприятия.

На основании учетных бухгалтерских проводок и операций составляем бухгалтерскую и статистическую отчетность. Она служит основой для оценки основных средств и анализа эффективности основных средств.

К анализу основных средств методические подходы совершенствуются. Для анализа основных средств есть разные методики. Методики сходны в первоначальном подходе к анализу состава, структуры и динамики основных средств.

Для целей проведения анализа основных средств предприятий различных видов деятельности применяется несколько методов. Существуют методические подходы: метод горизонтального анализа, метод вертикального анализа, метод сравнительного анализа, метод анализа финансовых коэффициентов.

Для определения влияния факторов на показатель основных средств проводят факторный анализ. Это анализ факторов, которые влияют на основные средства в процессе производства продуктов. 
Авторы методических подходов Савицкая Г.В. [7] и Шеремет А.Д. [6] пишут в своих трудах, что важным элементом анализа основных средств является оценка доли основных средств в общей структуре активов. Нужно проводить анализ структуры и динамики основных средств, давать оценку темпов роста и прироста основных средств за ряд отчетных периодов. Для оценки эффективности использования основных средств нужно использовать показатели отдачи их, как в общем, по основным средствам, так и в отдельности. По каждой группе в классификации найти показатели фондоотдачи, фондорентабельности. Также необходимо проводить анализ состояния основных средств по показателям поступления и выбытия, коэффициенту износа и коэффициенту годности основных средств.

Рассмотрим поведение показателя фондоотдачи активной части основных средств. Показатель фондоотдачи используется для оценки эффективности использования основных фондов предприятия,

Фондоотдача - наиболее обобщающий показатель экономической эффективности основных средств. Фондоотдача - экономический показатель, который определяет количество продукции, производимой на один рубль основных фондов. Фондоотдача рассчитывается как отношение стоимости продукции к средней стоимости основных средств.

Есть слабые стороны показателя фондоотдачи. В большом производстве, где используются дорогие основные средства, уровень фондоотдачи на момент начальной стадии производства ниже, чем планируемый. Это из-за того, что производство еще не достигло уровня полной мощности по выпуску продукции. На уменьшение фондоотдачи влияет показатель увеличения балансовой стоимости основных средств, недавно, введенных основных средств. В дальнейшем, в процессе производства, балансовая стоимость основных средств уменьшается за счет начисленной амортизации. Когда предприятие выходит на стадию полного развития и выпуск продукции, превышает плановый. В этот период показатель фондоотдачи увеличивается.

Нужно учесть, что не всегда балансовая стоимость равна рыночной «справедливой» [5] стоимости основных средств.

Еще нужно учесть влияние рисков при расчете фондоотдачи. Проявляются риски в изменении спроса и изменении цен на данный продукт в увеличении стоимости сырья, энергоресурсов и рабочей силы. Что существенно повышают затраты. Еще влияет высокая конкуренция в отрасли, в мировых масштабах, что проявляется не загруженностью производственных мощностей. 
Еще влияют риски на стоимость выпуска продукции, повышение процентных ставок, изменение курса валют, наличие у конкурентов дешевых технологий, ситуация с COVID-19, демографические проблемы.

В результате рисков выпуск продукции может уменьшиться. C уменьшением выпуска продукции и фондоотдача основных средств уменьшается. Хотя те же основные средства и работают на полную мощность. В этом проявляется сложность анализа дорогих основных средств на крупных производствах.

И, конечно, всегда есть возможности для лучшего использования показателя фондоотдачи. Делают расчет для каждого конкретного активно работающего основного средства. Вводят индекс - показатель влияния на стоимость выпуска продукции и стоимость основных средств. Для анализа показателя фондоотдачи риски и возможности можно вводить индексами при планировании производства.

Вывод: будем решать вопросы бухгалтерского учета и анализа основных средств. Затем анализировать данные бухгалтерского учета по основным средствам, чтобы создавать достоверную информацию и совершенствовать методику оценки основных средств и их эффективности. Это аналитическое обеспечение, отображающие финансовые потоки, создаст возможность управлять основными средствами. Нужно стараться инвестировать в новейшие основные средства, которые будут генерировать новейшие полезные для общества продукты, приносящих обществу не только прибыль, но и «заботу о человеке». При анализе крупных проектов, всегда есть такая мысль, как провести крупную постройку оборудования или модернизацию, чтобы соответствовать «надеждам» на прибыль. Эта сложность решается и окупается во времени. Нужно только двигаться по пути развития технического прогресса.

\section{Список литературы}

1. Федеральный закон от 6 декабря 2011 г. N402-Ф3 "О бухгалтерском учете".

2. Приказ Минфина РФ от 13.10.2003 N91н. (ред. от 24.12.2010, с изм. от 23.01.2020) "Об утверждении Методических указаний по бухгалтерскому учету основных средств" (Зарегистрировано в Минюсте РФ. 21.11.2003 N5252). 
3. 3 Приказ Минфина России от 30.03.2001 N26н. (ред. от 16.05.2016) "Об утверждении Положения по бухгалтерскому учету "Учет основных средств "ПБУ 6/01" (Зарегистрировано в Минюсте России. 28.04.2001 N2689).

4. Общероссийский классификатор ОК013-2014 (СНC 2008) "Общероссийский классификатор основных фондов" (принят и введен в действие приказом Федерального агентства по техническому регулированию и метрологии от 12 декабря 2014 г. N2018-ст) Дата введения - 1 января 2017 г.

5. Савицкая Г.В. Экономический анализ: Уч. / Г.В. Савицкая. - М.: Инфра-М, 2018. - 285c.

6. Плотникова О.В. Концепция конструктивного обязательства в методологии и организации учета инструментов хеджирования. Автореферат диссертация доктора экономических наук. 08.00.12. Плотникова Олеся Владимировна. [Место защиты. Воронеж. гос. ун-т]. Воронеж. 2014 44 с. Экономика

7. Шеремет А.Д. Анализ и диагностика финансово-хозяйственной деятельности предприятия: Учебник / А.Д. Шеремет. - М.: Инфра-М, 2017. $352 \mathrm{c}$.

8. Савицкая Г.В. Экономический анализ: Уч. / Г.В. Савицкая. - М.: Инфра-М, 2018. - 285c.

(C) Н.А. Семенихина, 2021 